\title{
Sustainable housing development in Nigeria: using low-carbon technology
}

\author{
A. A. Taiwo, G. Fadairo, Y. M. D. Adedeji \& A. O. Olotuah \\ Department of Architecture, Federal University of Technology, \\ Akure, Nigeria
}

\begin{abstract}
The housing situation in Nigeria is of deep concern for the government and the nation in the light of global warming. However, as studies have shown, the problem of housing is a universal one varying in different degrees from one country to another. Many buildings in Nigeria are inadequate qualitatively, and are located in insanitary environments. The paper examines a sustainable housing development process based on sustainable principles. The paper appraises sustainable housing development in Nigeria using low-carbon technology. This is with particular reference to the stabilized earth bricks as walling materials and the use of renewable energy through solar panels to generate power for such buildings in an environmentally friendly manner. Both embodied and operational energy uses on the buildings are examined with respect to the tropics within and outside the tropical region of the world.

Keywords: development, housing, low-carbon, sustainable, technology.
\end{abstract}

\section{Introduction}

Housing the urban dwellers is one of the major challenges facing mankind in the twenty-first century. Although studies have shown that the problem of housing is universal, it is however more critical in less developed countries (LDCs), including Nigeria. The challenge of housing the poor is particularly acute in the urban areas of LDCs where an explosive expansion of the urban population due to a high population growth rate and massive rural-urban drift has compounded the housing situation [1]. In most instances, the urban poor live in over-crowded housing, often in self-made temporary structures in slums and squatter settlements where they exert unprecedented pressure on deteriorating urban 
infrastructure and social services [2]. Nigeria has one of the highest urban growth rates in the world. The incidence of this population in urban centres has created severe housing problems, resulting in overcrowding in inadequate dwellings, and in a situation in which $60 \%$ of Nigerians can be said to be "houseless persons" [3, 4].

Research has confirmed the profound inadequacy in the housing circumstances of Nigerians, in particular the low-income population $[5,6]$. Olotuah and Fasakin [5] have shown that the housing circumstances of lowincome earners, who incidentally constitute the vast majority of the population in Nigeria, have not shown any significant improvement over the years. There is the incidence of massive rural-urban drift, which has been occasioned by the lack of development of the rural areas, the urban bias of government in locating public infrastructure, and the poor economic conditions of the rural dwellers. The urban population has grown too, through an increase in the size of the urban households.

Aside from the incidence of overcrowding in the existing housing stock, rural-urban drift has occasioned the sprouting of makeshift dwellings that are devoid of minimum structural and normative quality. The houses are constructed with all sorts of refuse materials in illegally occupied land, they are badly maintained and lack sanitary facilities, light, air and privacy. The greater proportion of the urban population generally lives in squalor, and in sub-standard and poor housing that is situated in deplorable conditions and an insanitary environment. As shown by past researches on housing studies of most urban centres in the country are characterized by high density of buildings, acute sanitary problems, pollution of air, surface water, noise and solid wastes [7, 8].

Climate change brought about by human-made emissions of greenhouse gases has been identified as the greatest challenge facing human society in this century. It refers to any significant change in measures of climate (such as temperature, precipitation, or wind) lasting for an extended period (decades or longer). Climate change may result from:

- natural factors, such as changes in the sun's intensity or slow changes in the Earth's orbit around the sun;

- natural processes within the climate system (e.g. changes in ocean circulation);

- human activities that change the atmosphere's composition (e.g. through burning fossil fuels) and the land surface (e.g. deforestation, reforestation, urbanization, desertification, etc.)

Tackling climate change requires concerted action. This will include reducing carbon dioxide emissions by changing the ways in which buildings are designed, constructed, managed and used. It is important to remember in the wider context for action to properly address the issue of climate change with reference to the built environment. Buildings should be constructed with low carbon technology, but they should also be sustainably designed; that is they should be created with consideration with the wider, long-term environmental, social and economic aspects of sustainability. 


\section{Sustainable housing development process}

Sustainable development can be described as that which meets the needs of the present, without compromising the ability of future generations to meet their own needs. This definition may not be immediately applicable to less developed countries (LDCs) against the background of the level of housing provision. But it is a pointer that concerted efforts should be made by various national governments of the less developed countries to phase out this transition period which should be based on ways of using the present earth's resources to more sustainable practice in the area of increasing housing stock. Most of the less developed countries are presently confronted with a relatively large deficit of housing requirements, a very high occupancy ratio in most cities, lack of basic provision of infrastructural facilities like pipe borne water, water closet, electricity etc., a large volume of solid waste generated especially in the cities, unsanitary conditions in which the solid wastes are collected, processed and disposed of, and so many more - all contributing towards environmental degradation. What then could be done in order to match growth with development in the less developed countries? There is a need to really establish what the problems are, how to find solutions to them and the best method that can be adopted to achieve a comfortable result within a limited time frame.

Gilkinson and Sexton [9] stated that sustainable housing is a form of affordable housing that incorporates environmentally friendly and communitybased practices. It attempts to reduce the negative impact that homes can have on the environment through choosing better building materials and environmental designs. Olotuah [10] asserted that concern for the environment is imperative in sustainable housing. This is important in the face of changes in climatic conditions occasioned by human activities, which are likely to have significant impact on man. The phenomenon of climate change and global warming has arisen from the continued emission of carbon dioxide and other Green House Gases into the atmosphere. The reduction of carbon dioxide emissions in house construction and domestic housing is thus a critical issue in environmental management. Consideration should also be given to the durability, permeability and buildability of defined material resources; the structures fixity, structural stability and acoustic attributes [9].

\section{Low carbon technology - use of stabilized earth bricks}

Low carbon technologies have a vital role to play in the move towards a green and sustainable environment. Such technologies have the potentials to reduce the carbon intensity of processes at every stage of the energy supply chain - from low carbon energy generation, through storage and transmission, to end user efficiency. In doing so, carbon dioxide emissions will be sustained. Sustainable and low embodied energy options for building materials can be used. Energy efficiency measures can be implemented through the installation of a number of existing technologies such as cavity wall and the use of bricks or stabilized earth bricks. Stabilized earth bricks are made from a mixture of earth or soil, sand with 
cement or lime as the stabilizer and water. The percentage of cement of lime ranges between 5 and 10. It is compacted into a high density block and then cured. This paper focuses on the use of stabilized earth bricks as a low carbon material used in construction of buildings with very low emission of carbon dioxide.

As a result of global economic recession, developing countries, particularly Nigeria, are reconsidering earth (laterite) as a suitable material for building construction works because earth is freely available, endowed with remarkable qualities of plasticity and thermal inertia [11]. In countries characterized by relatively humid and raining weather, like Nigeria, earth is not itself a particularly durable building material. Because of its exposure to rain water which causes erosion, instability and movement. Thus, in the past, much effort was usually being expended in protecting and repairing earth structures, with Zinc sheets being used to cover the lower walls of building as means of protection against erosion. If earth is to be used more frequently as a building material, its performance must be improved upon in order to make it as attractive and structurally stable as possible. Stabilized Compressed Earth Bricks (S.C.E.B) is a modified form of earth which is one of the oldest materials commonly used for building construction works. The S.C.E.B can stand as the best alternative to ordinary and unstabilized earth bricks. The basic raw materials needed to produce stabilized, compressed earth brick is soil with a good grain size distribution and a small percentage of cement as binder to provide good cohesive performances as suggested by Ogunsusi and Kolawole [12].

Sustainability in the built environment involves promoting energy efficient buildings and minimising their harm on our environment. To achieve this, industries, homes, offices and farms in every community must work together in becoming more sustainable. Truly sustainable development will improve economic efficiency, while protecting and restoring ecological systems, and enhancing the well-being of people in general. Environmental sustainability involves maintaining the environment at a constant level without damaging it further. It has been estimated that buildings contribute $40-50 \%$ of greenhouse gas emissions globally.

Adedeji et al. [13] observed that sustainable housing provision is the gradual, continual and replicable process of meeting the housing needs of the populace, the vast majority of who are poor and are incapable of providing adequately for themselves. It ensures housing strategies that are stable and are not subject to vagaries in the political circumstances of the country. Sustainable housing provision requires proper definition of housing needs, and the participation of the end users to ensure their satisfaction. The general goal of sustainable development is to meet the essential needs of the world's poor while ensuring that future generations have an adequate resources base to meet theirs. It is thus geared towards meeting the needs of the present generation without compromising the ability of future ones to meet their own needs. 


\section{Impact of stabilized earth bricks}

The earth as building material is found in great abundance all over the six geopolitical zones of Nigeria. Therefore, it then means that the stabilized earth bricks can be manufactured in almost anywhere in Nigeria. For the stabilized earth bricks to make any impact on the housing sector, it must be widely preferred to any basic building material. But preference of building material is a function of many factors - cost, availability, technology, psychology and government promotion. Where the stabilized earth bricks have been accepted and used, it has been observed that time taken for the construction of such buildings take relatively short time to complete. Interlocking stabilized earth bricks are fast gaining acceptance in terms of usage among urban dwellers in Nigeria. The stabilized earth bricks were used recently to construct the Electronic Testing Centre of the Federal University of Technology, Akure. Several buildings at the National Museum of Traditional Architecture in Jos Nigeria were constructed with the stabilized earth bricks.



Figure 1: Production of stabilized earth bricks.

\section{Why build with stabilized earth bricks?}

Building houses from laterite materials has a long illustrious past. For virtually all of history, our ancestors lived in shelters fashioned from locally available materials, especially laterite. Today, approximately half of the world's population of about 7 billion people still inhabit dwellings made with soils 
harvested from the earth's crust [14]. Stabilized earth brick houses are appropriate for a variety of climates and are ideally suited for passive solar heating and cooling. If designed well, they stay warm in cold seasons and cool in the hot seasons with little, if any, need for auxiliary or mechanical energy. Built largely from soil excavated on site, stabilized earth brick houses require substantially less fossil fuel-derived energy to build, than the conventional concrete buildings commonly found in many urban centres in less developed countries. Reduced energy consumption provides a wide range of environmental benefits, including reductions in greenhouse gas emissions. Figure 1 above shows work men and women processing the stabilized earth bricks. While figure 2 shows the recently built Electronic Testing Centre at the Federal University of Technology, Akure in Nigeria.

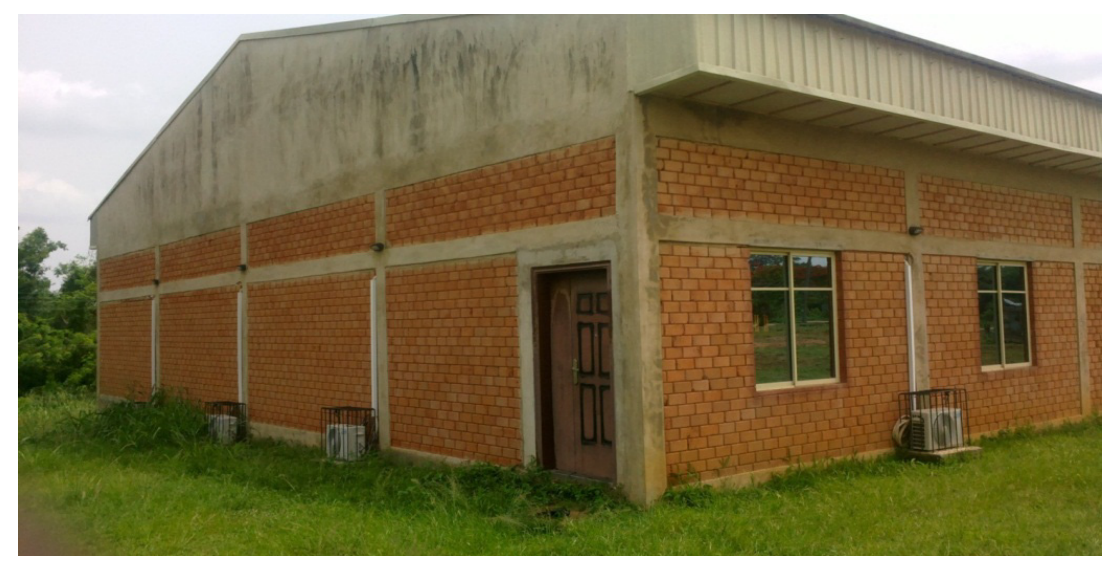

Figure 2: The Electronic Testing Centre of the Federal University of Technology, Akure, Nigeria built with stabilized earth bricks.

Stabilized earth brick buildings help to ease pressure on the world's overharvested forests. Materials used for its construction are collected locally: no huge mines are required to supply building materials, and the blemish produced when extracting laterite can generally be repaired quickly and easily with little environmental impact. For example, a hole dug to extract clay-rich materials for an adobe house, can be filled in and re-graded naturally.

\section{Embodied and operating energy in buildings}

The operating energy of a building is the amount of energy that is consumed by a building to satisfy the demand for heating, cooling, ventilation, lighting, equipment, and appliances. Operating energy is a convenient way to compare the energy consumption of different building systems, as its independent of the materials used. Instead, operating energy deals with the amount of renewable or non-renewable energy required to maintain the building functions and occupant activities. There are two forms of energy: non-renewable (e.g. coal, oil, natural 
gas) and renewable (e.g. solar, wind, water). Most buildings around the world depend heavily on the use of non-renewable energy. Although operating energy is the majority of energy consumed by buildings, the embodied energy of the materials that compose buildings is an important consideration. Embodied energy is the energy used in production and distribution of a product or material. The embodied energy of building materials contributes between 15 and $20 \%$ of the energy used by a building over a 50 year period. Architects and builders can specify materials with low embodied energy, thus reducing the amount of fossilfuel energy used during production. Also, as the operating energy is reduced through efficient design and technology, embodied energy becomes more important in reducing a building's carbon footprint.

\section{Conclusion}

This paper examines sustainable housing development process based on sustainable principles. It appraises sustainable housing development in Nigeria using low-carbon technology. Stabilized earth bricks are used extensively as walling materials in Nigeria offering low carbon solutions. The use of interlocking masonry (dry masonry technique) especially for low-cost housing for the urban poor in Nigeria has also emerged as research findings on housing sustainability. It is a low carbon construction technique and is cost effective. The use of renewable energy through solar panels to generate power for buildings in an environmentally friendly manner was also examined.

\section{References}

[1] Olotuah, A. O. and Bobadoye, S. A. (2009) Sustainable Housing Provision for the Urban Poor: A Review of Public Sector Intervention in Nigeria The Built \& Human Environment Review, Volume 2, 51.

[2] Diogu, J.O. (2002) Housing the Poor in Nigeria: The Integrated Project Approach, Association of Architectural Educators in Nigeria (AARCHES) Journal, 2(1) 1-6.

[3] Federal Government of Nigeria. (2004) National Housing Policy Draft, Abuja.

[4] Olotuah, A. O. and Ajenifujah A. O., (2009) Architectural Education and Housing Provision in Nigeria. CEBE Transactions, Vol. 6, Issue 1, pp. 86102, April 2009 (17) ISSN: 1745-0322 (Online) 86.

[5] Olotuah, A. O. and Fasakin, J. O. (2003) Housing requirements of lowincome civil servants in Ado-Ekiti: A critico-empirical investigation. The Journal of Urban and Environmental Research, 3 (1), 55-59.

[6] Olotuah, A. O. and Aiyetan, A. O. (2006) Sustainable low-cost housing provision in Nigeria: a bottom-up, participatory approach. In Boyd, D. (Ed.) Proceedings of $22^{\text {nd }}$ Annual ARCOM Conference, 4-6 September, Birmingham, UK, Association of Researchers in Construction Management, Vol. 2, pp. 633-639. 
[7] Filani, M. O. (1987) Accessibility and urban poverty in Nigeria. In Makinwa, P. K. and Ozo, O. A. (Eds.) The urban poor in Nigeria. Ibadan: Evans Brothers (Nig.) Publishers Ltd, pp. 128-136.

[8] Agbola, S. B. (1998) The housing of Nigerians - A review of policy development and implementation. Research Report No. 14. Ibadan, Nigeria: Development Policy Centre.

[9] Gilkinson, N. and Sexton, M. (2007) Delivering Sustainable Homes; Meeting Requirements: A Research Agenda, Proceedings of XXXV IAHS World Congress on Housing Science, Melbourne, Australia, 4-7 September, CD ROM.

[10] Olotuah, A. O. (2010) Housing Development and Environment Degeneration in Nigeria, The Built \& Human Environment Review, Volume 3, 42-48.

[11] Arayela, O. (2002) "Sustainable Housing Development Policy for Developing Countries of Africa -Nigeria as case study" Conference Proceedings on Housing Construction - An Interdisciplinary Task. Eds. Professors Oktay Ural, Vitor Abrantes and Antonio Tadeu, Portugal, pp. 967-974.

[12] Ogunsusi, V. and Kolawole, P. (1994): Compressed Earth Bricks Masonry - Brick Product 2. Jos: Centre for Earth Construction Technology (CEC Tech), pp. 6 - 29.

[13] Adedeji, Y.M.D. Taiwo, A. A. Olotuah O. A. and Fadairo G. (2011) Architectural education and sustainable human habitat in Nigeria, Sustainability Today, WIT Transactions on Ecology and The Environment, Vol. 167, 89-99. 